\title{
Unusual Effects of Nicotine as a Psychostimulant on Ambulatory Activity in Mice
}

\author{
Toyoshi Umezu \\ Biological Imaging and Analysis Section, Center for Environmental Measurement and Analysis, \\ National Institute for Environmental Studies, 16-2 Onogawa, Tsukuba 305-8506, Japan \\ Correspondence should be addressed to Toyoshi Umezu, umechan2@nies.go.jp
}

Received 25 November 2011; Accepted 26 December 2011

Academic Editors: H. Y. Lane and L. D. Reid

Copyright ( 92012 Toyoshi Umezu. This is an open access article distributed under the Creative Commons Attribution License, which permits unrestricted use, distribution, and reproduction in any medium, provided the original work is properly cited.

The present study examined the effect of nicotine, alone and in combination with various drugs that act on the CNS, on ambulatory activity, a behavioral index for locomotion, in ICR (CD-1) strain mice. Nicotine at $0.25-2 \mathrm{mg} / \mathrm{kg}$ acutely reduced ambulatory activity of ICR mice. The effect of nicotine was similar to that of haloperidol and fluphenazine but distinct from that of bupropion and methylphenidate. ICR mice developed tolerance against the inhibitory effect of nicotine on ambulatory activity when nicotine was repeatedly administered. This effect was also distinct from bupropion and methylphenidate as they produced augmentation of their ambulation-stimulating effects in ICR mice. Nicotine reduced the ambulation-stimulating effects of bupropion and methylphenidate as well as haloperidol and fluphenazine. Taken together, nicotine exhibited unusual effects as a psychostimulant on ambulatory activity in ICR mice.

\section{Introduction}

Nicotine (NIC), the primary psychoactive substance in tobacco smoke, produces a variety of psychoactive effects and has been believed to be a type of psychostimulant. In humans, NIC produces convulsions, tremors, and excitation of respiration [1], elevates the arousal level $[2,3]$, facilitates behaviors and performance [4-6], and improves cognition and attention abilities [7-10]. These effects support the idea that NIC is a type of psychostimulant. On the other hand, other studies suggest that NIC may have depressant and/or sedative effects [11-14]. In addition, it is well known that prolonged use of typical psychostimulants such as amphetamine, methamphetamine, and cocaine causes schizophrenialike mental abnormalities (amphetamine (or methamphetamine) psychosis, and cocaine psychosis) [15-21] whereas prolonged smoking has been known not to produce schizophrenia-like psychosis. In contrast, smoking has been proposed as a form of self-medication to alleviate symptoms of schizophrenia [22-28]. The self-medication hypothesis arose from the following observations: (1) patients with schizophrenia frequently smoke cigarettes at a two- to fourfold higher rate than that seen in the general population;
(2) patients with schizophrenia smoke heavier than the normal population [29-35]; (3) patients with schizophrenia extract more nicotine from each cigarette than other smokers [36]. Thus, smoking may ameliorate symptoms of schizophrenia, and the NIC in cigarettes could contribute to the heavy smoking that has been noted in patients with schizophrenia. If the self-medication hypothesis for NIC in patients with schizophrenia is true, the effect of NIC in patients with schizophrenia is in striking contrast to the effects of typical psychostimulants in these patients as typical psychostimulants usually worsen schizophrenia or produce schizophrenia-like psychosis.

In animals, locomotion is a fundamental behavioral index for evaluating the stimulating effects of psychostimulants. Typical psychostimulants such as amphetamine [3742], methamphetamine [43-50], and cocaine [49, 51-56] consistently stimulate locomotion in rats and mice. In terms of rodent locomotion, NIC may exhibit different properties from those of typical psychostimulants. NIC usually stimulates locomotion in rats to a small degree but frequently fails to produce locomotor hyperactivity in mice [57-66]. Although genetic factors could be involved in species and/or strain differences for effects of NIC on locomotion in rodents 
[67], the effects of NIC on rodent locomotion should largely depend on pharmacological properties of NIC, as typical psychostimulants consistently stimulate locomotion in any species and/or strains of rodents. The effects of NIC on locomotion in rodents are still controversial.

Ambulatory activity is a kind of locomotor activity for mice and can be measured using a tilt-type ambulometer [68]. Because effects of many kinds of psychoactive drugs have been evaluated using this method [69-88], using ambulatory activity as a behavioral index has been well established. The present study examined the effect of NIC, alone and in combination with various CNS acting drugs, on ambulatory activity in ICR (or CD-1) strain mice, which is one of the popular strains for general multipurpose use.

\section{Materials and Methods}

2.1. Animals. Male ICR (CD-1) strain mice (Clea Japan, Tokyo, Japan) aged 7-10 weeks and weighing between 35 and $42 \mathrm{~g}$ were housed in aluminum cages ( 3 mice/cage) with a stainless-steel mesh top and paper bedding. Commercial solid food (Clea Japan) and tap water were available ad libitum. Cages were placed in a room artificially illuminated by fluorescent lamps on a 12L:12D schedule (light period: 07:00-19:00), at a room temperature of $25 \pm 1^{\circ} \mathrm{C}$.

All experiments were conducted in accordance with the guidelines of the Ethics Committee for Experimental Animals of the National Institute for Environmental Studies, Japan.

2.2. Drugs. NIC was purchased from Nacalai Tesque (Kyoto, Japan). Psychostimulants bupropion (BUP) and methylphenidate (MP; Ritalin) were purchased from Sigma-Aldrich (Tokyo, Japan) and Japan Ciba-Geigy (Hyogo), respectively. CNS depressants fluphenazine (FLU), haloperidol (HAL), and nAChR antagonist mecamylamine (MECA) were purchased from Sigma-Aldrich. NIC, BUP, MP, FLU, and MECA were dissolved in saline $(0.9 \% \mathrm{NaCl}$, Nacalai Tesque). $\mathrm{HAL}$ was dissolved in $0.1 \%$ acetic acid solution (Wako Pure Chemicals, Osaka, Japan).

2.3. Measurement of Ambulatory Activity in ICR Mice. Ambulatory activity was measured using a tilt-type ambulometer consisting of 10 bucket-like Plexiglas activity cages $(20 \mathrm{~cm}$ in diameter) (SAM-10; O'Hara and Co., Tokyo, Japan) ([68, 89, 90], in press (DOI: 10.1016/j.ntt.2011.08.007), [91-93]). Each activity cage is sustained by a fulcrum in the center of the bottom of the cage; the fulcrum tilts according to horizontal movement of the mouse in the activity cage. The tilting movement of the activity cage activates microswitches that surround the cage. The number of activations of microswitches during a set time is recorded, and the result is printed.

\section{Experimental Procedure}

Experiment 1. Effect of a single subcutaneous administration of NIC on ambulatory activity in ICR mice.
ICR mice were placed individually in activity cages, and, after $30 \mathrm{~min}$ of adaptation, saline or $0.25,0.5,1$, or $2 \mathrm{mg} / \mathrm{kg}$ of NIC was administered subcutaneously. Thereafter, ambulatory activity was continuously measured for $60 \mathrm{~min}$.

Experiment 2. Effects of single subcutaneous administrations of BUP, MP, HAL, or FUL on ambulatory activity in ICR mice.

After $30 \mathrm{~min}$ of adaptation in the activity cages, saline or 5 or $10 \mathrm{mg} / \mathrm{kg}$ of BUP, 2 or $4 \mathrm{mg} / \mathrm{kg}$ of MP, 0.031, 0.0625 , or $0125 \mathrm{mg} / \mathrm{kg}$ of HAL, or $0.625,0.125$, or $0.25 \mathrm{mg} / \mathrm{kg}$ of FLU was subcutaneously administered to ICR mice. Thereafter, ambulatory activity was continuously measured for $60 \mathrm{~min}$.

Experiment 3. Effect of repeated administrations of NIC, BUP, or MP on ambulatory activity.

After 30 min of adaptation in the activity cages, saline or $1 \mathrm{mg} / \mathrm{kg}$ of NIC, $10 \mathrm{mg} / \mathrm{kg}$ of BUP, or $4 \mathrm{mg} / \mathrm{kg}$ of MP was administered to mice, and ambulatory activity was measured for $60 \mathrm{~min}$. These steps were repeated on the same mice 5 times with 3- to 4-day intervals and changes of effects of these drugs on ambulatory activity were examined.

Experiment 4. Interaction between NIC and MECA on ambulatory activity.

After 30 min of adaptation in the activity cages, saline or $1 \mathrm{mg} / \mathrm{kg}$ of MECA was subcutaneously administered to mice. Ten minutes later, saline or $2 \mathrm{mg} / \mathrm{kg}$ of NIC was subcutaneously administered to the mice, followed by measurements of ambulatory activity for $60 \mathrm{~min}$.

Experiment 5. Interactions between BUP and HAL or FLU or between NIC and BUP or MP on ambulatory activity.

After 30 min of adaptation in the activity cages, saline or $0.031,0.0625$, or $0.125 \mathrm{mg} / \mathrm{kg}$ of HAL or $0.0625,0.125$, or $0.25 \mathrm{mg} / \mathrm{kg}$ of FLU was subcutaneously administered to mice. Ten minutes later, saline or $10 \mathrm{mg} / \mathrm{kg}$ of BUP was subcutaneously administered to the mice, followed by measurements of ambulatory activity for $60 \mathrm{~min}$.

After $30 \mathrm{~min}$ of adaptation in the activity cages, saline or $0.25,0.5,1$, or $2 \mathrm{mg} / \mathrm{kg}$ of NIC and saline, $10 \mathrm{mg} / \mathrm{kg}$ of BUP, or $4 \mathrm{mg} / \mathrm{kg}$ of MP were subcutaneously coadministered to mice, followed by measurements of ambulatory activity for $60 \mathrm{~min}$.

3.1. Statistical Analysis. To eliminate differences of baseline ambulatory activity, the activity of each animal after administration of each drug was normalized using the total activity of the animal during the $30 \mathrm{~min}$ adaptation period before administration of each drug.

The time course of ambulatory activity after single administration of NIC was initially examined using repeated-measures analysis of variance (ANOVA). Then, differences at each time point were examined using oneway ANOVA, followed by Dunnett's test. Differences in total ambulatory activity over $1 \mathrm{~h}$ were analyzed using one-way ANOVA, followed by Dunnett's test. $P<0.05$ was established as the level of significance. 


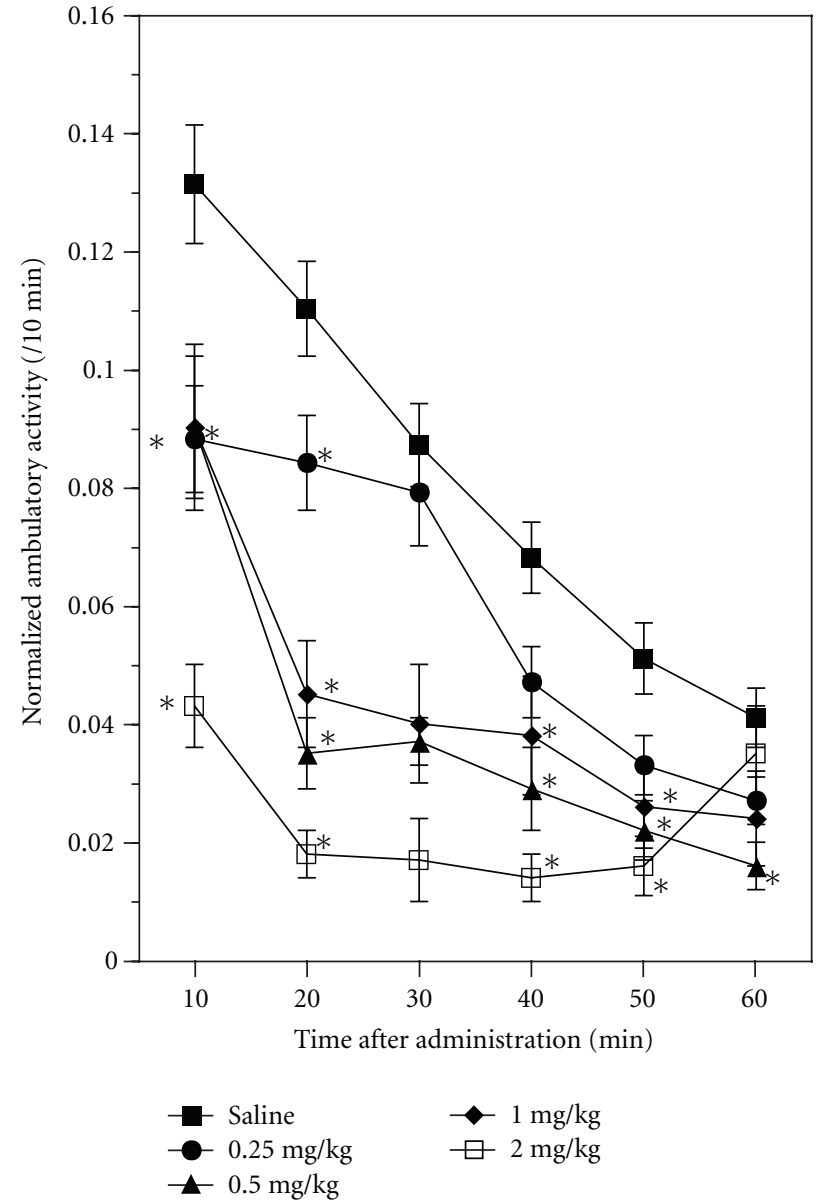

(a)

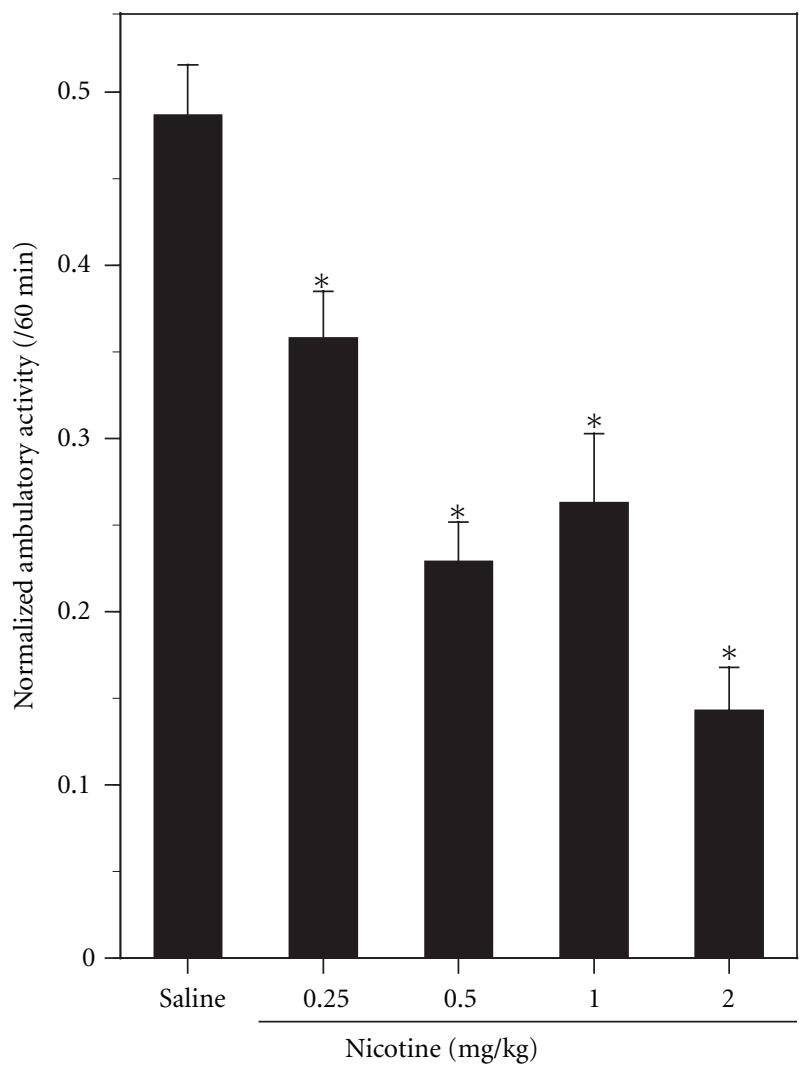

(b)

Figure 1: Ambulatory activity in ICR mice after single subcutaneous administration of saline or $0.25-2 \mathrm{mg} / \mathrm{kg}$ of NIC. The figure shows normalized ambulatory activity that was obtained by normalizing the actual ambulatory measurement using total ambulatory activity during the $30 \mathrm{~min}$ adaptation period before administration to each mouse. (a) Time courses of ambulatory activity after subcutaneous administration of saline or $0.25-2 \mathrm{mg} / \mathrm{kg}$ of NIC. Symbols represent mean values of ambulatory activity for 10 min periods, and vertical lines indicate standard error of the mean (SEM). $N=40-100$ animals per dose group. (b) Total ambulatory activity over 60 min after administration of saline or various doses of NIC. Filled columns indicate mean values of total ambulatory activity for 60 min, and vertical lines indicate SEM. Data in Figure 1(a) were analyzed by repeated measures ANOVA, followed by one-way ANOVA and Dunnett's test. ${ }^{*} P<0.05$ compared with saline control at each time point. Data in Figure 1(b) were analyzed using one-way ANOVA, followed by Dunnett's test. ${ }^{*} P<0.05$ compared with saline control.

\section{Results}

Experiment 1. Effect of a single subcutaneous administration of NIC on ambulatory activity in ICR mice.

NIC at $0.25-2 \mathrm{mg} / \mathrm{kg}$ significantly reduced the ambulatory activity of ICR mice (Figures $1(\mathrm{a})$ and $1(\mathrm{~b})$ ). The effect of NIC was dose dependent (Figure $1(\mathrm{~b}) ; F(4,275)=20.1$, $P<0.05)$ and lasted as long as $60 \mathrm{~min}-$ Figure $1(\mathrm{a})$; repeated measures ANOVA (dose: $F(4,275)=20.1, P<0.05$; time: $F(5,1375)=61.896, P<0.05$; interaction: $F(20,1375)=$ 5.582, $P<0.05)$.

Experiment 2. Effects of single subcutaneous administrations of BUP, MP, HAL, or FUL on ambulatory activity in ICR mice.
BUP at $5-10 \mathrm{mg} / \mathrm{kg}$ (Figure 2(a)) and MP at $2-4 \mathrm{mg} / \mathrm{kg}$ (Figure 2(b)) stimulated ambulatory activity of ICR mice in a dose-dependent manner (BUP: $F(2,217)=26.132, P<0.05$; MP: $F(2,317)=100.433, P<0.05)$.

$\mathrm{HAL}$ at $0.031-0.125 \mathrm{mg} / \mathrm{kg}$ (Figure 2(c)) and FLU at $0.625-0.25 \mathrm{mg} / \mathrm{kg}$ (Figure $2(\mathrm{~d})$ ) significantly and dose-dependently reduced the ambulatory activity in ICR mice (HAL: $F(3,68)=5.945, P<0.05$; FLU: $F(3,64)=2.907, P<0.05)$.

Experiment 3. Effect of repeated administrations of NIC, BUP, or MP on ambulatory activity.

Repeated administration of saline to the same mice with intervals of 3-4 days did not significantly alter normalized ambulatory activity of ICR mice (Figures 3(a), 3(b), and $3(\mathrm{c}) ; F(4,595)=2.373, P>0.05)$. The inhibitory effect of 


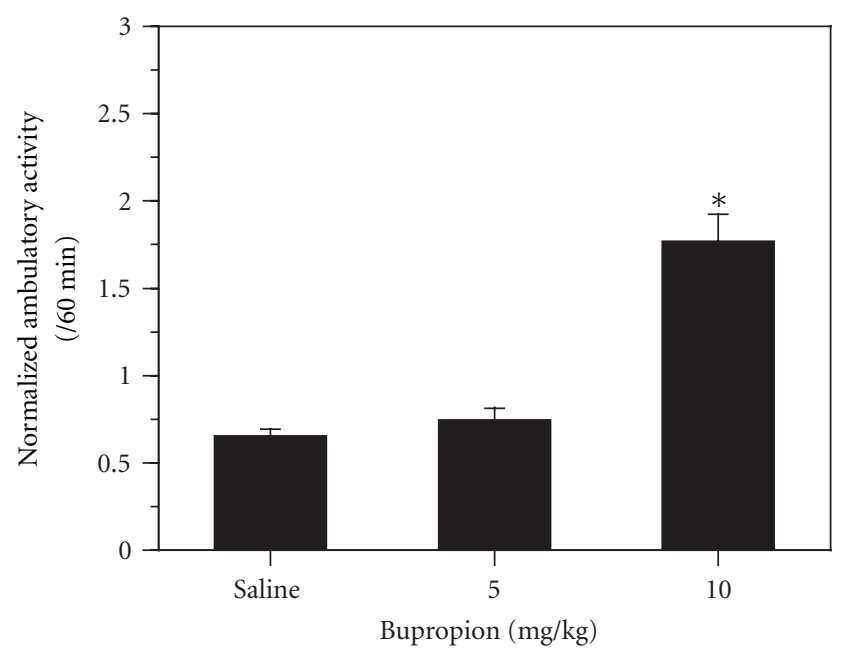

(a)

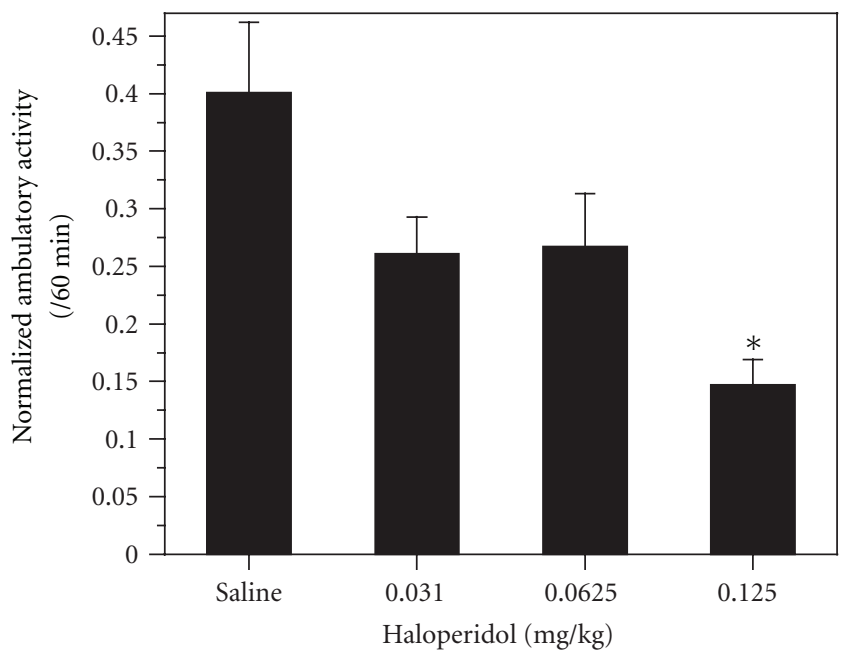

(c)

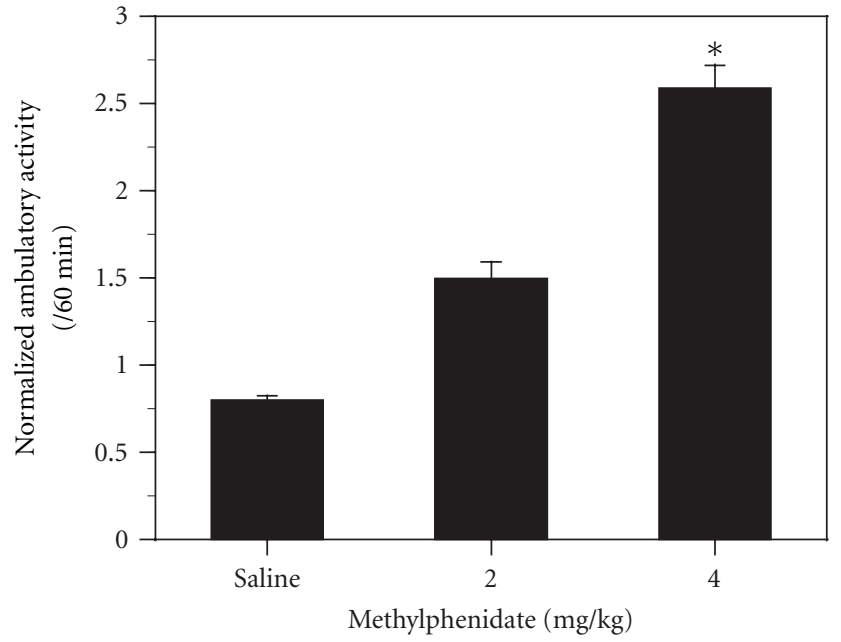

(b)

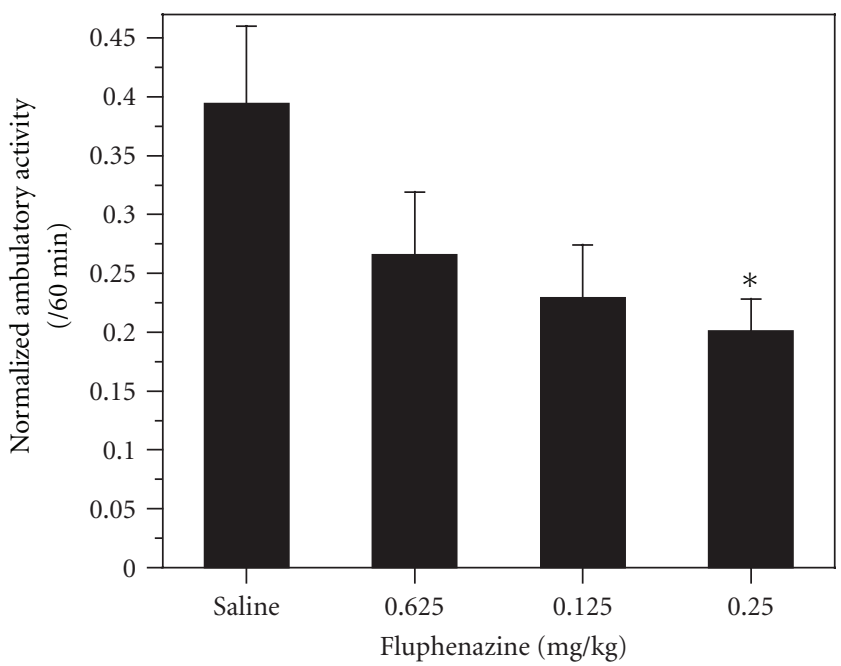

(d)

Figure 2: Effects of single subcutaneous administrations of $5-10 \mathrm{mg} / \mathrm{kg}$ of BUP (a), 2-4 mg/kg of MP (b), 0.031-0.125 mg/kg of HAL (c), or $0.625-0.25 \mathrm{mg} / \mathrm{kg}$ of FLU (d) on ambulatory activity in ICR mice. Results are shown using normalized values. Filled columns indicate mean values of total ambulatory activity for $60 \mathrm{~min}$, and vertical lines indicate SEM. (a) $N=40-120$, (b) $N=100-120$, (c) $N=18$, and (d) $N=$ 16-18. $* P<0.05$ compared with saline control.

$1 \mathrm{mg} / \mathrm{kg}$ of NIC on ambulatory activity gradually attenuated during repeated administration with intervals of 3-4 days (Figure 3(a)). Analysis of variance failed to show statistical significance on the change of effect of NIC $(F(4,95)=2.433$, $P=0.0527$ ); however, significant differences between saline control and NIC observed at the first three administrations disappeared at the last two administrations, indicating that the inhibitory effect of NIC gradually weakened. The ambulation-stimulating effect of $10 \mathrm{mg} / \mathrm{kg}$ of BUP (Figure $3(\mathrm{~b})$ ) and $4 \mathrm{mg} / \mathrm{kg}$ of MP (Figure $3(\mathrm{c})$ ) gradually and significantly increased when they were administered repeatedly to the same mice with intervals of 3-4 days (BUP: $F(3,236)=4.942, P<0.05 ; \mathrm{MP} ; F(4,494)=10.489$, $P<0.05$ ) (Figures $3(\mathrm{~b})$ and $3(\mathrm{c})$ ).

Experiment 4. Interaction between NIC and MECA on ambulatory activity.
NIC at $2 \mathrm{mg} / \mathrm{kg}$ significantly reduced the ambulatory activity and $1 \mathrm{mg} / \mathrm{kg}$ of MECA eliminated the inhibitory effect of $2 \mathrm{mg} / \mathrm{kg}$ of NIC on ambulatory activity when administered together (Figure 4; $F(2,137)=5.598, P<0.05)$.

Experiment 5. Interactions between BUP and HAL or FLU or between NIC and BUP or MP on ambulatory activity.

HAL at $0.031-0.125 \mathrm{mg} / \mathrm{kg}$ (Figure 5(a)) and $0.0625-$ $0.25 \mathrm{mg} / \mathrm{kg}$ of FLU (Figure 5 (b)) significantly reduced the ambulation-stimulating effect of $10 \mathrm{mg} / \mathrm{kg}$ of BUP in a dosedependent manner (HAL: $F(4,115)=21.148, P<0.05$; FLU: $F(4,185)=15.622, P<0.05)$. Similarly, $0.25-2 \mathrm{mg} / \mathrm{kg}$ of NIC significantly reduced the ambulation-stimulating effect of $10 \mathrm{mg} / \mathrm{kg}$ of BUP in a dose-dependent manner (Figure 5(c); $F(5,234)=23.778, P<0.05)$. The same doses of NIC also significantly reduced the ambulation-stimulating 


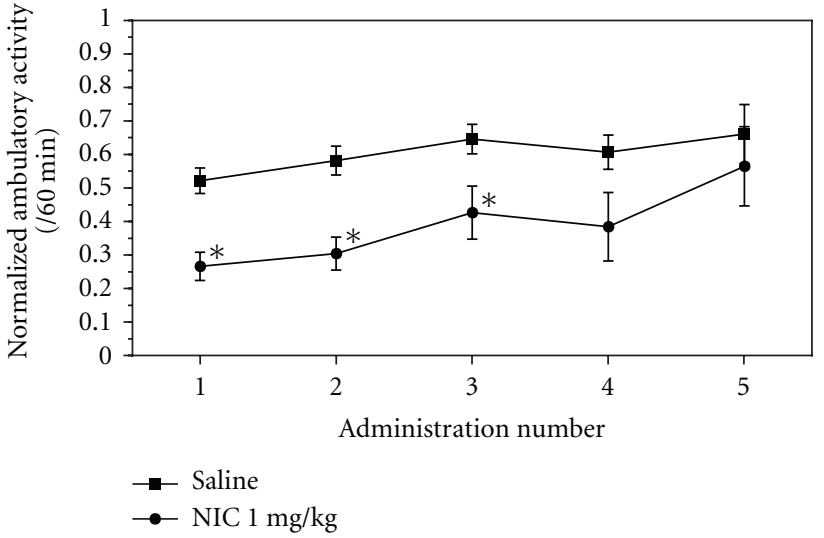

(a)

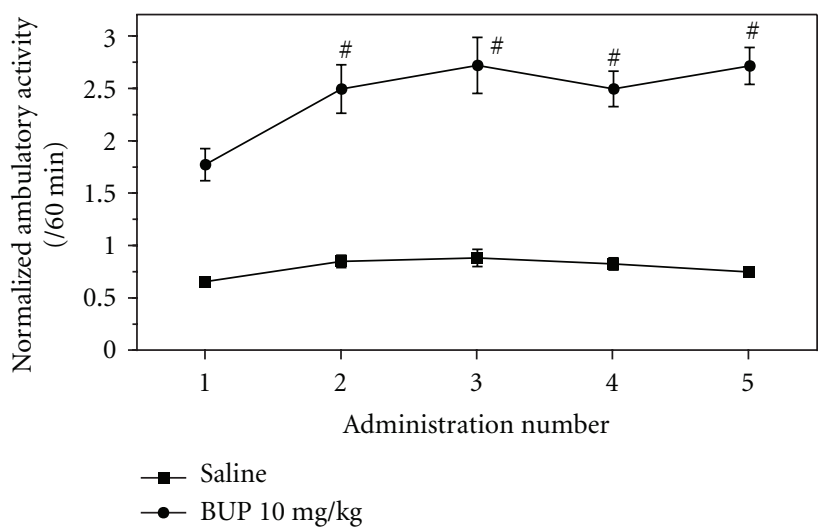

(b)

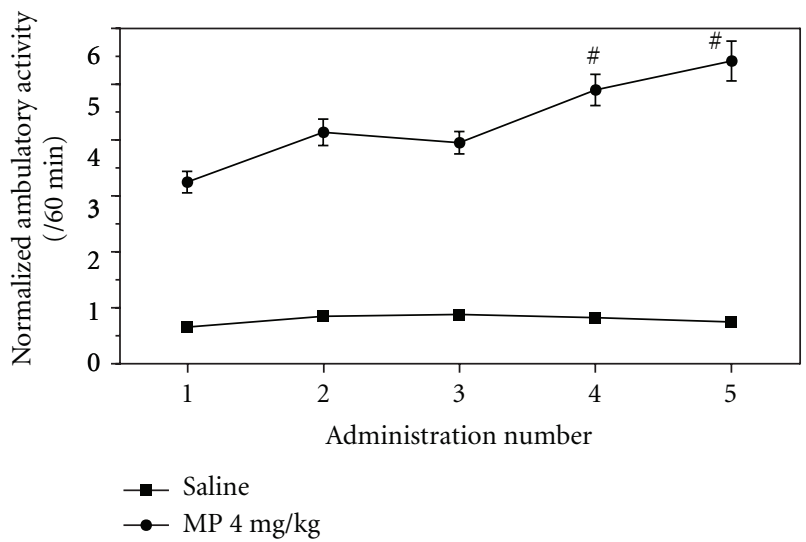

(c)

FIGURE 3: Effects of repeated administrations of saline or $1 \mathrm{mg} / \mathrm{kg}$ of NIC (a), $10 \mathrm{mg} / \mathrm{kg}$ of BUP (b), or $4 \mathrm{mg} / \mathrm{kg}$ of MP (c) to the same ICR mice on ambulatory activity. The administration was repeated 5 times with intervals of 3-4 days. Symbols represent mean values of ambulatory activity for 60 min periods after the administrations, and vertical lines indicate SEM. Saline: $N=60$, NIC: $N=20$, BUP: $N=60$, and MP: $N=100 .{ }^{*} P<0.05$ compared with saline control at the same time point. ${ }^{*} P<0.05$ compared with the first administration of the drug.

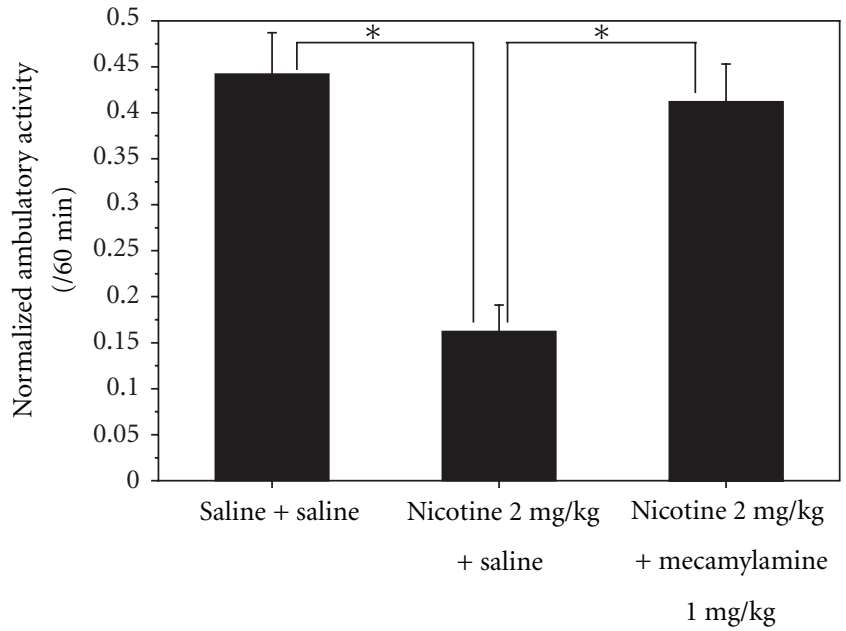

Figure 4: Effects of combined administration of $2 \mathrm{mg} / \mathrm{kg}$ of NIC with $1 \mathrm{mg} / \mathrm{kg}$ of MECA on ambulatory activity. Filled columns indicate mean values of total ambulatory activity for $60 \mathrm{~min}$ after the administrations, and vertical lines indicate SEM. Saline + saline: $N=80$, NIC + saline: $N=20$, and NIC + MECA: $N=40 .{ }^{*} P<$ 0.05 compared with NIC + saline. effect of $4 \mathrm{mg} / \mathrm{kg}$ of MP (Figure $5(\mathrm{~d}) ; F(5,194)=23.86$, $P<0.05)$.

\section{Discussion}

Ambulatory activity measured using a tilt-type ambulometer is sensitive to vertical movement of mice in the activity cage of the ambulometer but insensitive to vertical movement of animals. Therefore, ambulatory activity can be used as a measure of behavioral indices for locomotion in mice. This notion is further supported by results of the previous [9193] and present studies that show the ambulatory activity of ICR (CD-1) mice was stimulated by psychostimulants such as BUP and MP, which have been known to stimulate mouse locomotion [94-99], and reduced by depressants such as HAL and FLU, which have been known to reduce mouse locomotion [98, 100-102].

The present study revealed that NIC at $0.25-2 \mathrm{mg} / \mathrm{kg}$ acutely reduced ambulatory activity in ICR mice under the same experimental condition for evaluating effects of psychostimulants BUP and MP and depressants HAL and FLU. Psychostimulants sometimes cause stereotyped or repetitive 


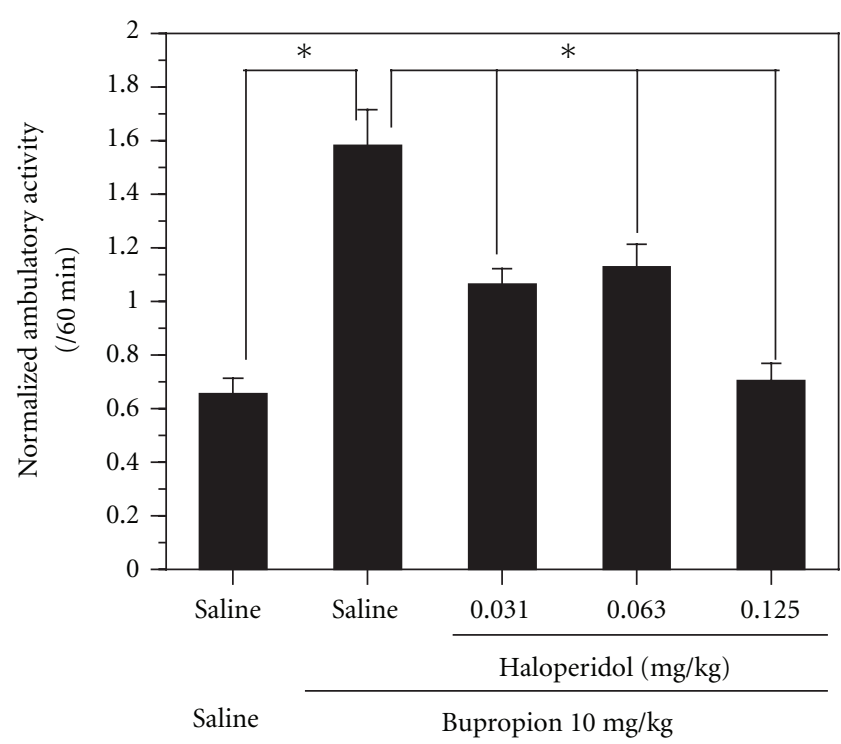

(a)

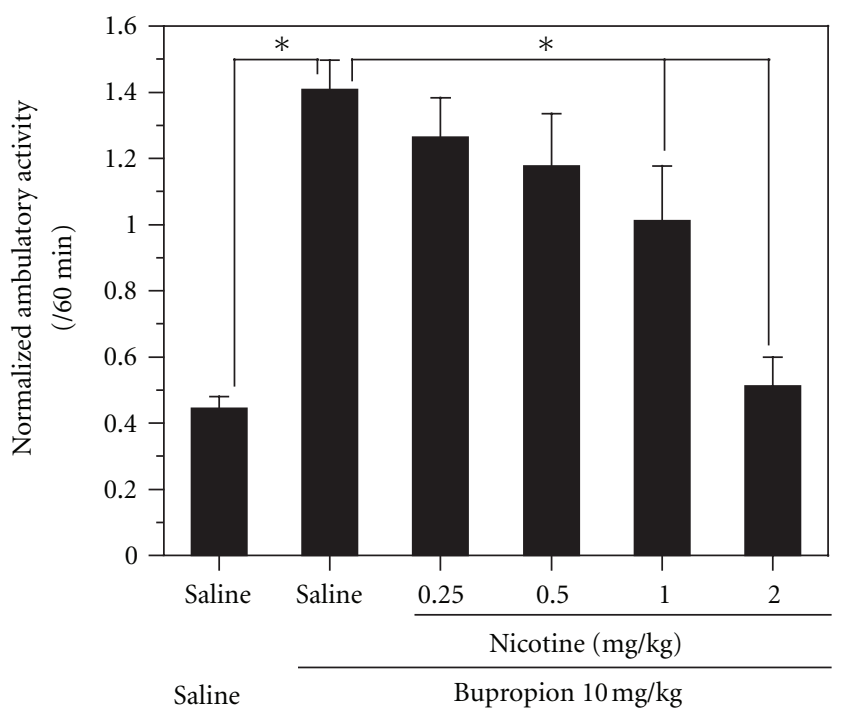

(c)

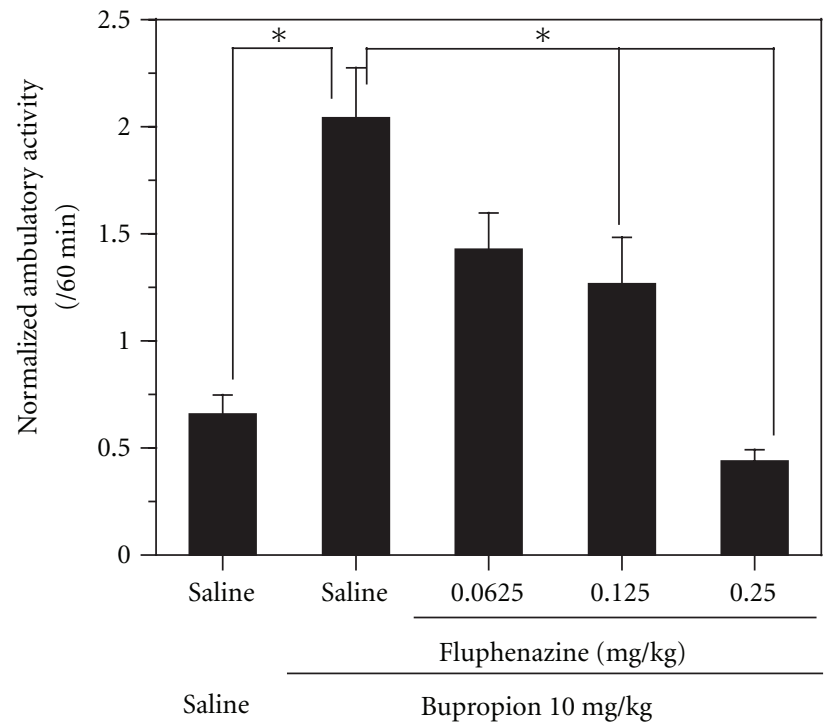

(b)

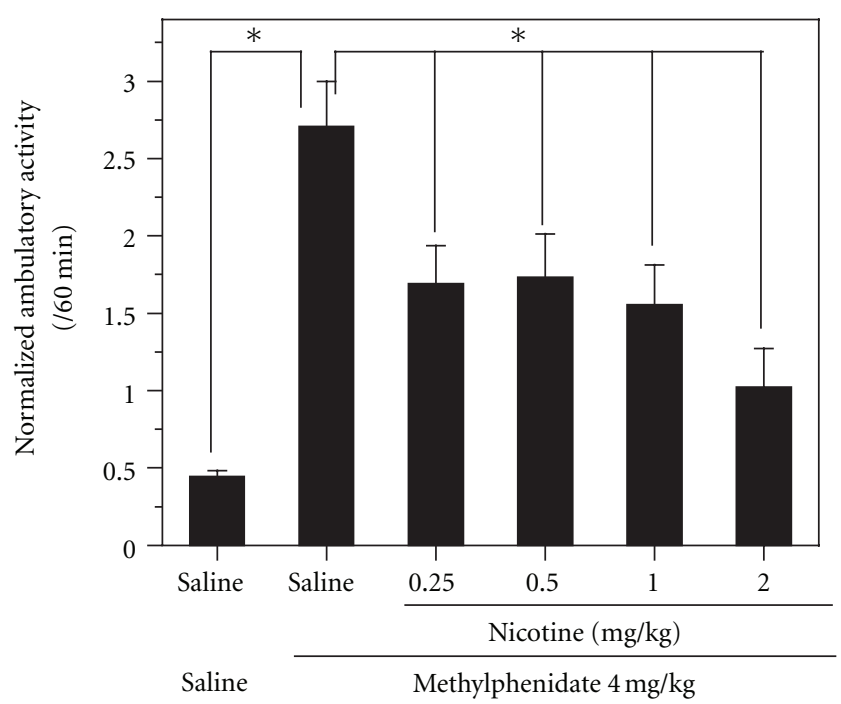

(d)

Figure 5: Effects of combined administrations of $10 \mathrm{mg} / \mathrm{kg}$ of BUP with $0.031-0.125 \mathrm{mg} / \mathrm{kg}$ of HAL (a), 0.0625-0.25 mg/kg of FLU (b), or $0.25-2 \mathrm{mg} / \mathrm{kg}$ of NIC (c) or combined administration of $4 \mathrm{mg} / \mathrm{kg}$ of MP with $0.25-2 \mathrm{mg} / \mathrm{kg}$ of NIC (d) on ambulatory activity in ICR mice. Filled columns represent mean values of ambulatory activity for $60 \mathrm{~min}$ after the administrations, and vertical lines indicate SEM. (a) $N=$ 20-40, (b) $N=30-50$, (c) $N=20-80$, and (d) $N=20-40 .{ }^{*} P<0.05$ compared with BUP + saline or MP + saline.

behaviors (i.e., stereotypy) that are able to cause decrease of the ambulatory activity measurement of mice. However, NIC at $0.25-2 \mathrm{mg} / \mathrm{kg}$ did not produce such effect in ICR mice but animals exhibited less activity or sedation in the bucket-like activity cage. Because previous studies have also shown that $0.1-3 \mathrm{mg} / \mathrm{kg}$ of NIC produces hypoactivity on locomotion in ICR mice $[60,103,104]$, it is possible to conclude that NIC acutely reduces locomotion in ICR mice. This locomotor effect of NIC in ICR mice is distinct from the effects of psychostimulants such as BUP and MP.

The idea that NIC exhibits distinct properties on locomotor effects from those of psychostimulants in ICR mice is further supported by results in the present study that examined effects of repeated administration of NIC, BUP, and MP. It is well established that repeated administration of psychostimulants to the same animals produces augmented responses to these agents, a phenomena referred to as behavioral sensitization. BUP and MP also produce the same properties as psychostimulants on locomotor effects in rodents [105109], and the properties of BUP and MP were confirmed in ICR mice in the present study. On the other hand, ICR mice developed tolerance against the inhibitory effect of NIC on the ambulatory activity when NIC was repeatedly administered. Thus, NIC produces unusual properties as a psychostimulant on locomotion in ICR mouse.

NIC exhibited effects similar to depressants such as HAL and FLU rather than psychostimulants such as BUP and MP on locomotion of ICR mice in this study; that is, 
NIC reduced the ambulatory activity of ICR mice and the ambulation-stimulating effects of BUP and MP. These results suggest that NIC may lead to similar effects as HAL and FLU. It has been reported that NIC is able to ameliorate symptoms such as deficits of cognition and/or attention in animal models for psychosis as well as the effects of antipsychotics [110-117], indicating that NIC exhibits similar pharmacological properties to antipsychotics in animals. Thus, the idea in which NIC produces similar effects to antipsychotics in rodents has already been known; however, it has not been elucidated whether this notion is true for effects of NIC on rodent locomotion. The present study revealed that NIC exhibits similar effects as antipsychotics such as HAL and FLU on locomotion in ICR mice. Both BUP and MP are able to induce psychosis-like illnesses in humans [118129], and the psychosis-like illnesses could be ameliorated by antipsychotics such as HAL and FLU. In light of these observations and the results of the present study, the selfmedication hypothesis for heavy smoking among patients with schizophrenia [22-28] seems reasonable. NIC may reduce psychomotor excitation that accompanies with schizophrenia, and such efficacy of nicotine may be involved in heavy smoking in schizophrenia patients [29-35].

Neuronal acetylcholine receptors (nAChRs) could be involved in the inhibitory effect of NIC on ambulatory activity in ICR mice as the nAChRs antagonist, MECA, ameliorated the effect of NIC. nAChRs are known to be involved in the inhibitory effect of NIC on locomotion in $\mathrm{C} 57 \mathrm{Bl} / 6$ mice [63, 130]. ICR mice developed tolerance against the inhibitory effect of NIC on ambulatory activity when NIC was repeatedly administered. C57Bl/6 mice also develop tolerance against the inhibitory effect on locomotion when NIC was chronically or repeatedly administered, and the development of tolerance is accompanied by changes in nAChRs in the brain $[63,130]$. The involvement of nAChRs in the inhibitory effect of NIC and in the development of tolerance against the NIC effect on locomotion in $\mathrm{C} 57 \mathrm{Bl} / 6$ mice suggests that nAChRs may play similar roles in locomotor effects of NIC in ICR mice.

The neurotransmitter dopamine (DA) might also be involved in the effects of NIC on ambulatory activity in ICR mice. Because both BUP and MP enhance DA neurotransmission through inhibition of its reuptake [96, 131-136], changes of DA neurotransmission could be involved in the ambulation-stimulating effects of these agents. The involvement of DA in the ambulation-stimulating effect of BUP in ICR mice is further supported by the present results in which both HAL and FLU, which possess DA receptor antagonizing abilities, reduced the ambulation-stimulating effect of BUP in ICR mice. Because effects of NIC observed in the present study were similar to those of HAL and FLU, it is probable that NIC influences DA neurotransmission to reduce ambulatory activity and the ambulation-stimulating effects of BUP and MP in ICR mice. Because nAChRs are directly and/or indirectly able to affect DA neurotransmission [137-140], interaction between nAChRs and the DA system might account for the effects of NIC on ambulatory activity in ICR mice.

\section{Acknowledgment}

This study was supported by the Smoking Research Foundation, Japan.

\section{References}

[1] A. G. Goodman, Ed., Goodman and Gilman's The Pharmacological Basis of Therapeutics, Pergamon Press, New York, NY, USA, 8th edition, 1990.

[2] J. E. Henningfield, "Behavioral pharmacology of cigarette smoking," Advances in Behavioral Pharmacology, vol. 4, pp. 131-210, 1984.

[3] E. F. Domino, "Nicotine: a unique psychoactive drug. Arousal with skeletal muscle relaxation," Psychopharmacology Bulletin, vol. 22, no. 3, pp. 870-874, 1986.

[4] K. A. Perkins, L. H. Epstein, R. L. Stiller, J. E. Sexton, T. D. Debski, and R. G. Jacob, "Behavioral performance effects of nicotine in smokers and nonsmokers," Pharmacology Biochemistry and Behavior, vol. 37, no. 1, pp. 11-15, 1990.

[5] G. J. Spilich, L. June, and J. Renner, "Cigarette smoking and cognitive performance," British Journal of Addiction, vol. 87, no. 9, pp. 1313-1326, 1992.

[6] S. J. Heishman, B. A. Kleykamp, and E. G. Singleton, "Metaanalysis of the acute effects of nicotine and smoking on human performance," Psychopharmacology, vol. 210, no. 4, pp. 453-469, 2010.

[7] B. Hahn, T. J. Ross, F. A. Wolkenberg, D. M. Shakleya, M. A. Huestis, and E. A. Stein, "Performance effects of nicotine during selective attention, divided attention, and simple stimulus detection: an fMRI study," Cerebral Cortex, vol. 19, no. 9, pp. 1990-2000, 2009.

[8] G. E. Swan and C. N. Lessov-Schlaggar, "The effects of tobacco smoke and nicotine on cognition and the brain," Neuropsychology Review, vol. 17, no. 3, pp. 259-273, 2007.

[9] A. Mendrek, J. Monterosso, S. L. Simon et al., "Working memory in cigarette smokers: comparison to non-smokers and effects of abstinence," Addictive Behaviors, vol. 31, no. 5, pp. 833-844, 2006.

[10] M. Ernst, S. J. Heishman, L. Spurgeon, and E. D. London, "Smoking history and nicotine effects on cognitive performance," Neuropsychopharmacology, vol. 25, no. 3, pp. 313319, 2001.

[11] D. G. Gilbert, "Paradoxical tranquilizing and emotion-reducing effects of nicotine," Psychological Bulletin, vol. 86, no. 4, pp. 643-661, 1979.

[12] J. B. Acri, "Nicotine modulates effects of stress on acoustic startle reflexes in rats: dependence on dose, stressor and initial reactivity," Psychopharmacology, vol. 116, no. 3, pp. 255265, 1994.

[13] D. G. Gilbert, J. H. Robinson, C. L. Chamberlin, and C. D. Spielberger, "Effects of smoking/nicotine on anxiety, heart rate, and lateralization of EEG during a stressful movie," Psychophysiology, vol. 26, no. 3, pp. 311-320, 1989.

[14] S. B. Morissette, M. T. Tull, S. B. Gulliver, B. W. Kamholz, and R. T. Zimering, "Anxiety, anxiety disorders, tobacco use, and nicotine: a critical review of interrelationships," Psychological Bulletin, vol. 133, no. 2, pp. 245-272, 2007. 
[15] M. Srisurapanont, S. Arunpongpaisal, K. Wada, J. Marsden, R. Ali, and R. Kongsakon, "Comparisons of methamphetamine psychotic and schizophrenic symptoms: a differential item functioning analysis," Progress in NeuroPsychopharmacology and Biological Psychiatry, vol. 35, no. 4, pp. 959-964, 2011.

[16] N. Kuzenko, J. Sareen, K. Beesdo-Baum et al., "Associations between use of cocaine, amphetamines, or psychedelics and psychotic symptoms in a community sample," Acta Psychiatrica Scandinavica, vol. 123, no. 6, pp. 466-474, 2011.

[17] K. Akiyama, A. Saito, and K. Shimoda, "Chronic methamphetamine psychosis after long-term abstinence in Japanese incarcerated patients," American Journal on Addictions, vol. 20, no. 3, pp. 240-249, 2011.

[18] E. Yokobayashi, H. Ujike, T. Kotaka et al., "Association study of serine racemase gene with methamphetamine psychosis," Current Neuropharmacology, vol. 9, no. 1, pp. 169-175, 2011.

[19] B. Angrist, G. Sathananthan, S. Wilk, and S. Gershon, "Amphetamine psychosis: behavioral and biochemical aspects," Journal of Psychiatric Research, vol. 11, pp. 13-23, 1974.

[20] Y. L. Tang, H. R. Kranzler, J. Gelernter, L. A. Farrer, D. Pearson, and J. F. Cubells, "Transient cocaine-associated behavioral symptoms rated with a new instrument, the scale for assessment of positive symptoms for cocaine-induced psychosis (SAPS-CIP)," American Journal on Addictions, vol. 18, no. 5, pp. 339-345, 2009.

[21] J. V. Nunes and P. A. Broderick, "Novel research translates to clinical cases of schizophrenic and cocaine psychosis," Neuropsychiatric Disease and Treatment, vol. 3, no. 4, pp. 475-485, 2007.

[22] A. H. Glassman, "Cigarette smoking: implications for psychiatric illness," American Journal of Psychiatry, vol. 150, no. 4, pp. 546-553, 1993.

[23] T. H. Svensson, J. Grenhoff, and G. Engberg, "Effect of nicotine on dynamic function of brain catecholamine neurons," Ciba Foundation Symposium, vol. 152, pp. 169-180, 1990.

[24] C.-S. Tung, J. Grenhoff, and T. H. Svensson, "Nicotine counteracts midbrain dopamine cell dysfunction induced by prefrontal cortex inactivation," Acta Physiologica Scandinavica, vol. 138, no. 3, pp. 427-428, 1990.

[25] M. Nisell, G. G. Nomikos, and T. H. Svensson, "Nicotine dependence, midbrain dopamine systems and psychiatric disorders," Pharmacology and Toxicology, vol. 76, no. 3, pp. 157162, 1995.

[26] V. Kumari and P. Postma, "Nicotine use in schizophrenia: the self medication hypotheses," Neuroscience and Biobehavioral Reviews, vol. 29, no. 6, pp. 1021-1034, 2005.

[27] Y. Tizabi, "Nicotine and nicotinic system in hypoglutamatergic models of schizophrenia," Neurotoxicity Research, vol. 12, no. 4, pp. 233-246, 2007.

[28] A. Olincy and K. E. Stevens, "Treating schizophrenia symptoms with an $\alpha 7$ nicotinic agonist, from mice to men," Biochemical Pharmacology, vol. 74, no. 8, pp. 1192-1201, 2007.

[29] E. Masterson and B. O'Shea, "Smoking and malignancy in schizophrenia," British Journal of Psychiatry, vol. 145, pp. 429-432, 1984.

[30] J. R. Hughes, D. K. Hatsukami, J. E. Mitchell, and L. A. Dahlgren, "Prevalence of smoking among psychiatric outpatients," American Journal of Psychiatry, vol. 143, no. 8, pp. 993-997, 1986.
[31] D. C. Goff, D. C. Henderson, and E. Amico, "Cigarette smoking in schizophrenia: relationship to psychopathology and medication side effects," American Journal of Psychiatry, vol. 149, no. 9, pp. 1189-1194, 1992.

[32] A. Diwan, M. Castine, C. S. Pomerleau, J. H. MeadorWoodruff, and G. W. Dalack, "Differential prevalence of cigarette smoking in patients with schizophrenic vs mood disorders," Schizophrenia Research, vol. 33, no. 1-2, pp. 113-118, 1998.

[33] C. Kelly and R. G. McCreadie, "Smoking habits, current symptoms, and premorbid characteristics of schizophrenic patients in Nithsdale, Scotland," American Journal of Psychiatry, vol. 156, no. 11, pp. 1751-1757, 1999.

[34] K. Lasser, J. W. Boyd, S. Woolhandler, D. U. Himmelstein, D. McCormick, and D. H. Bor, "Smoking and mental illness: a population-based prevalence study," JAMA, vol. 284, no. 20, pp. 2606-2610, 2000.

[35] J. De Leon, M. Dadvand, C. Canuso, A. O. White, J. K. Stanilla, and G. M. Simpson, "Schizophrenia and smoking: an epidemiological survey in a state hospital," American Journal of Psychiatry, vol. 152, no. 3, pp. 453-455, 1995.

[36] A. Olincy, D. A. Young, and R. Freedman, "Increased levels of the nicotine metabolite cotinine in schizophrenic smokers compared to other," Biological Psychiatry, vol. 42, no. 1, pp. $1-5,1997$.

[37] D. Li, S. Herrera, N. Bubula et al., "Casein kinase 1 enables nucleus accumbens amphetamine-induced locomotion by regulating AMPA receptor phosphorylation," Journal of Neurochemistry, vol. 118, no. 2, pp. 237-247, 2011.

[38] J. J. Cortright, D. S. Lorrain, J. A. Beeler, W.-J. Tang, and P. Vezina, "Previous exposure to $\Delta 9$-tetrahydrocannibinol enhances locomotor responding to but not self-administration of amphetamine," Journal of Pharmacology and Experimental Therapeutics, vol. 337, no. 3, pp. 724-733, 2011.

[39] M. H. Baumann, Z. Williams, D. Zolkowska, and R. B. Rothman, "Serotonin (5-HT) precursor loading with 5-hydroxy-l-tryptophan (5-HTP) reduces locomotor activation produced by (+)-amphetamine in the rat," Drug and Alcohol Dependence, vol. 114, pp. 147-152, 2010.

[40] S. R. Kameda, D. F. Fukushiro, T. F. Trombin et al., "Adolescent mice are more vulnerable than adults to single injectioninduced behavioral sensitization to amphetamine," Pharmacology Biochemistry and Behavior, vol. 98, no. 2, pp. 320-324, 2011.

[41] S. Gormley and P.-P. Rompré, "Blockade of mGLUR5 receptors differentially alters amphetamine-induced enhancement of locomotor activity and of brain stimulation reward," Journal of Psychopharmacology, vol. 25, no. 3, pp. 393-401, 2011.

[42] X. Fan, M. Xu, and E. J. Hess, "D2 dopamine receptor subtype-mediated hyperactivity and amphetamine responses in a model of ADHD," Neurobiology of Disease, vol. 37, no. 1, pp. 228-236, 2010.

[43] B. A. McGuire, M. G. Baladi, and C. P. France, "Eating highfat chow enhances sensitization to the effects of methamphetamine on locomotion in rats," European Journal of Pharmacology, vol. 658, no. 2-3, pp. 156-159, 2011.

[44] T. Futamura, S. Akiyama, H. Sugino, A. Forbes, R. D. McQuade, and T. Kikuchi, "Aripiprazole attenuates established behavioral sensitization induced by methamphetamine," Progress in Neuro-Psychopharmacology and Biological Psychiatry, vol. 34, no. 6, pp. 1115-1119, 2010. 
[45] T. Uehara, T. Sumiyoshi, T. Seo et al., "Neonatal exposure to MK-801, an N-methyl-d-aspartate receptor antagonist, enhances methamphetamine-induced locomotion and disrupts sensorimotor gating in pre- and postpubertal rats," Brain Research, vol. 1352, pp. 223-230, 2010.

[46] D. A. Hall, J. P. Powers, and J. M. Gulley, "Blockade of D1 dopamine receptors in the medial prefrontal cortex attenuates amphetamine- and methamphetamine-induced locomotor activity in the rat," Brain Research, vol. 1300, pp. 5157, 2009.

[47] P. S. Clifford, N. Hart, J. Thompson et al., "Prenatal lead exposure enhances methamphetamine sensitization in rats," Pharmacology Biochemistry and Behavior, vol. 93, no. 2, pp. 165-169, 2009.

[48] R. L. Good and R. A. Radcliffe, "Methamphetamine-induced locomotor changes are dependent on age, dose and genotype," Pharmacology Biochemistry and Behavior, vol. 98, no. 1, pp. 101-111, 2011.

[49] J. A. Zombeck, A. D. Lewicki, K. Patel, T. Gupta, and J. S. Rhodes, "Patterns of neural activity associated with differential acute locomotor stimulation to cocaine and methamphetamine in adolescent versus adult male C57BL/6J mice," Neuroscience, vol. 165, no. 4, pp. 1087-1099, 2010.

[50] Y. Kaneko, A. Kashiwa, T. Ito, S. Ishii, A. Umino, and T. Nishikawa, "Selective serotonin reuptake inhibitors, fluoxetine and paroxetine, attenuate the expression of the established behavioral sensitization induced by methamphetamine," Neuropsychopharmacology, vol. 32, no. 3, pp. 658-664, 2007.

[51] S. Clifford, R. A. Zeckler, S. Buckman et al., "Impact of food restriction and cocaine on locomotion in ghrelin- and ghrelin-receptor knockout mice," Addiction Biology, vol. 16, no. 3, pp. 386-392, 2011.

[52] D. Thompson, L. Martini, and J. L. Whistler, "Altered ratio of $\mathrm{D}_{1}$ and $\mathrm{D}_{2}$ dopamine receptors in mouse striatum is associated with behavioral sensitization to cocaine," PLoS ONE, vol. 5, no. 6, Article ID e11038, 2010.

[53] K. R. Rodvelt, S. Z. Lever, J. R. Lever, L. R. Blount, K.-H. Fan, and D. K. Miller, "SA 4503 attenuates cocaine-induced hyperactivity and enhances methamphetamine substitution for a cocaine discriminative stimulus," Pharmacology Biochemistry and Behavior, vol. 97, no. 4, pp. 676-682, 2011.

[54] C. Brabant, L. Alleva, T. Grisar et al., "Effects of the H3 receptor inverse agonist thioperamide on cocaine-induced locomotion in mice: role of the histaminergic system and potential pharmacokinetic interactions," Psychopharmacology, vol. 202, no. 4, pp. 673-687, 2009.

[55] A. K. Stoker and A. Markou, "Withdrawal from chronic cocaine administration induces deficits in brain reward function in C57BL/6J mice," Behavioural Brain Research, vol. 223, no. 1, pp. 176-181, 2011.

[56] M. J. Acerbo and A. K. Johnson, "Behavioral crosssensitization between DOCA-induced sodium appetite and cocaine-induced locomotor behavior," Pharmacology Biochemistry and Behavior, vol. 98, no. 3, pp. 440-448, 2011.

[57] M. J. Marks, J. B. Burch, and A. C. Collins, "Genetics of nicotine response in four inbred strains of mice," Journal of Pharmacology and Experimental Therapeutics, vol. 226, no. 1, pp. 291-302, 1983.

[58] G. B. Freeman, K. A. Sherman, and G. E. Gibson, "Locomotor activity as a predictor of times and dosages for studies of nicotine's neurochemical actions," Pharmacology Biochemistry and Behavior, vol. 26, no. 2, pp. 305-312, 1987.
[59] T. Kita, T. Nakashima, M. Shirase, M. Asahina, and Y. Kurogochi, "Effects of nicotine on ambulatory activity in mice," Japanese Journal of Pharmacology, vol. 46, no. 2, pp. 141-146, 1988.

[60] M. I. Damaj and B. R. Martin, "Is the dopaminergic system involved in the central effects of nicotine in mice?" Psychopharmacology, vol. 111, no. 1, pp. 106-108, 1993.

[61] A. Smolen, M. J. Marks, J. C. DeFries, and N. D. Henderson, "Individual differences in sensitivity to nicotine in mice: response to six generations of selective breeding," Pharmacology Biochemistry and Behavior, vol. 49, no. 3, pp. 531-540, 1994.

[62] Y. Itzhak and J. L. Martin, "Effects of cocaine, nicotine, dizocipline and alcohol on mice locomotor activity: cocainealcohol cross-sensitization involves upregulation of striatal dopamine transporter binding sites," Brain Research, vol. 818, no. 2, pp. 204-211, 1999.

[63] J. A. Sparks and J. R. Pauly, "Effects of continuous oral nicotine administration on brain nicotinic receptors and responsiveness to nicotine in C57B1/6 mice," Psychopharmacology, vol. 141, no. 2, pp. 145-153, 1999.

[64] H. Gäddnäs, K. Pietilä, and L. Ahtee, "Effects of chronic oral nicotine treatment and its withdrawal on locomotor activity and brain monoamines in mice," Behavioural Brain Research, vol. 113, no. 1-2, pp. 65-72, 2000.

[65] A. Castañé, E. Valjent, C. Ledent, M. Parmentier, R. Maldonado, and O. Valverde, "Lack of CB1 cannabinoid receptors modifies nicotine behavioural responses, but not nicotine abstinence," Neuropharmacology, vol. 43, no. 5, pp. 857-867, 2002.

[66] A.-S. Villégier, L. Salomon, S. Granon et al., "Monoamine oxidase inhibitors allow locomotor and rewarding responses to nicotine," Neuropsychopharmacology, vol. 31, no. 8, pp. 1704-1713, 2006.

[67] K. J. Gill and A. E. Boyle, "Genetic basis for the psychostimulant effects of nicotine: a quantitative trait locus analysis in $\mathrm{AcB} / \mathrm{BcA}$ recombinant congenic mice," Genes, Brain and Behavior, vol. 4, no. 7, pp. 401-411, 2005.

[68] M. Hirabayashi, M. Iizuka, and S. Tadokoro, "Simple and easy method for measurement of ambulatory activity in mice," Folia Pharmacologica Japonica, vol. 74, no. 5, pp. 629639, 1978.

[69] H. Kuribara and S. Tadokoro, "Development of tolerance to ambulation-increasing effect of scopolamine dependent on environmental factors in mice," Japanese Journal of Pharmacology, vol. 33, no. 5, pp. 1041-1048, 1983.

[70] H. Kuribara and S. Tadokoro, "Circadian variation in the ambulation-increasing effect of apomorphine after repeated administration in mice," Japanese Journal of Psychopharmacology, vol. 4, no. 3, pp. 231-236, 1984.

[71] T. Asami, H. Kuribara, and S. Tadokoro, "Effects of repeated administration of bromocriptine on ambulatory activity in mice, and changes in methamphetamine sensitivity in bromocriptine-experienced mice," Japanese Journal of Psychopharmacology, vol. 6, no. 3, pp. 309-317, 1986.

[72] Y. Iijima, T. Asami, and H. Kuribara, "Modification by MK801 (dizocilpine), a noncompetitive NMDA receptor antagonist, of morphine sensitization: evaluation by ambulation in mice," Japanese Journal of Psychopharmacology, vol. 16, no. 1, pp. 11-18, 1996.

[73] K. Hirate and H. Kuribara, "Characteristics of the ambulation-increasing effect of GBR-12909, a selective dopamine uptake inhibitor, in mice," Japanese Journal of Pharmacology, vol. 55, no. 4, pp. 501-511, 1991. 
[74] H. Kuribara and Y. Uchihashi, "Dopamine antagonists can inhibit methamphetamine sensitization, but not cocaine sensitization, when assessed by ambulatory activity in mice," Journal of Pharmacy and Pharmacology, vol. 45, no. 12, pp. 1042-1045, 1993.

[75] H. Kuribara and Y. Uchihashi, "Effects of haloperidol on the methamphetamine sensitization: assessment by ambulatory activity in mice," Japanese Journal of Psychiatry and Neurology, vol. 47, no. 3, pp. 661-668, 1993.

[76] H. Kuribara and Y. Uchihashi, "Effects of dopamine antagonism on methamphetamine sensitization: evaluation by ambulatory activity in mice," Pharmacology Biochemistry and Behavior, vol. 47, no. 1, pp. 101-106, 1994.

[77] H. Kuribara, T. Asami, T. Saito, I. Ida, and S. Tadokoro, "Behavioral study on mergocriptine (CBM36-733) by ambulatory activity in mice: repeated administration and interaction with methamphetamine," Japanese Journal of Pharmacology, vol. 54, no. 2, pp. 163-170, 1990.

[78] H. Kuribara, T. Katsuya, T. Asahi, and S. Tadokoro, "Effects of repeated administration of buprenorphine on ambulatory activity in mice," Japanese Journal of Psychopharmacology, vol. 11, no. 2, pp. 123-127, 1991.

[79] H. Kuribara, T. Asami, I. Ida, and S. Tadokoro, "Characteristics of the ambulation-increasing effect of the noncompetitive NMDA antagonist MK-801 in mice: assessment by the coadministration with central-acting drugs," Japanese Journal of Pharmacology, vol. 58, no. 1, pp. 11-18, 1992.

[80] H. Kuribara, "Can posttreatment with the selective dopamine $\mathrm{D}_{2}$ antagonist, YM-O9151-2, inhibit induction of methamphetamine sensitization? Evaluation by ambulatory activity in mice," Pharmacology Biochemistry and Behavior, vol. 49, no. 2, pp. 323-326, 1994.

[81] H. Kuribara, "Dopamine $\mathrm{D}_{1}$ and $\mathrm{D}_{2}$ receptor antagonists suppress acute stimulant action of cocaine, but enhance cocaine sensitization," Japanese Journal of Psychiatry and Neurology, vol. 48, no. 4, pp. 907-911, 1994.

[82] H. Kuribara, "Modification by caffeine of the sensitization to methamphetamine and cocaine in terms of ambulation in mice," Life Sciences, vol. 55, no. 12, pp. 933-940, 1994.

[83] H. Kuribara, "Caffeine enhances the stimulant effect of methamphetamine, but may not affect induction of methamphetamine sensitization of ambulation in mice," Psychopharmacology, vol. 116, no. 2, pp. 125-129, 1994.

[84] H. Kuribara, "Effects of sulpiride and nemonapride, benzamide derivatives having distinct potencies of antagonistic action on dopamine $D_{2}$ receptors, on sensitization to methamphetamine in mice," Journal of Pharmacy and Pharmacology, vol. 48, no. 3, pp. 292-296, 1996.

[85] H. Kuribara, "Modification of morphine sensitization by opioid and dopamine receptor antagonists: evaluation by studying ambulation in mice," European Journal of Pharmacology, vol. 275, no. 3, pp. 251-258, 1995.

[86] H. Kuribara, "Caffeine enhances acute stimulant effect of morphine but inhibits morphine sensitization when assessed by ambulation of mice," Progress in Neuro-Psychopharmacology and Biological Psychiatry, vol. 19, no. 2, pp. 313-321, 1995.

[87] H. Kuribara, "Inhibition of methamphetamine sensitization by post-methamphetamine treatment with SCH 23390 or haloperidol," Psychopharmacology, vol. 119, no. 1, pp. 34-38, 1995.
[88] H. Kuribara, "Interaction between $\mathrm{D}_{1}$ and $\mathrm{D}_{2}$ antagonists in the inhibition of methamphetamine-induced ambulation in mice," Pharmaceutical Sciences, vol. 2, no. 3, pp. 141-144, 1996.

[89] T. Umezu, J. Yonemoto, Y. Soma, and T. Suzuki, “Tris(2chloroethyl)phosphate increases ambulatory activity in mice: pharmacological analyses of its neurochemical mechanism," Toxicology and Applied Pharmacology, vol. 148, no. 1, pp. 109-116, 1998.

[90] T. Umezu, A. Sakata, and H. Ito, "Ambulation-promoting effect of peppermint oil and identification of its active constituents," Pharmacology Biochemistry and Behavior, vol. 69, no. 3-4, pp. 383-390, 2001.

[91] T. Umezu and M. Morita, "Evidence for the involvement of dopamine in ambulation promoted by menthol in mice," Journal Pharmacological Sciences, vol. 91, no. 2, pp. 125-135, 2003.

[92] T. Umezu, "Evidence for dopamine involvement in ambulation promoted by menthone in mice," Pharmacology Biochemistry and Behavior, vol. 91, no. 3, pp. 315-320, 2009.

[93] T. Umezu, "Evidence for dopamine involvement in ambulation promoted by pulegone in mice," Pharmacology Biochemistry and Behavior, vol. 94, no. 4, pp. 497-502, 2010.

[94] R. Redolat, J. Vidal, M. C. Gómez, and M. C. Carrasco, "Effects of acute bupropion administration on locomotor activity in adolescent and adult mice," Behavioural Pharmacology, vol. 16, no. 1, pp. 59-62, 2005.

[95] P. Bredeloux, I. Dubuc, and J. Costentin, "Comparisons between bupropion and dexamphetamine in a range of in vivo tests exploring dopaminergic transmission," British Journal of Pharmacology, vol. 150, no. 6, pp. 711-719, 2007.

[96] S. K. Billes and M. A. Cowley, "Catecholamine reuptake inhibition causes weight loss by increasing locomotor activity and thermogenesis," Neuropsychopharmacology, vol. 33, no. 6, pp. 1287-1297, 2008.

[97] H. Tilleman, O. Kofman, L. Nashelsky et al., "Critical role of the embryonic mid-hindbrain organizer in the behavioral response to amphetamine and methylphenidate," Neuroscience, vol. 163, no. 4, pp. 1012-1023, 2009.

[98] K. M. Smith, D. M. Fagel, H. E. Stevens et al., "Deficiency in inhibitory cortical interneurons associated with hyperactivity in fibroblast growth factor receptor 1 mutant mice," Biological Psychiatry, vol. 63, no. 10, pp. 953-962, 2008.

[99] M. Niculescu, M. E. Ehrlich, and E. M. Unterwald, "Agespecific behavioral responses to psychostimulants in mice," Pharmacology Biochemistry and Behavior, vol. 82, no. 2, pp. 280-288, 2005.

[100] K. Minck, P. Danneberg, and F. Knappen, "Effects of psychotropic drugs on exploratory behavior of mice," Psychopharmacologia, vol. 39, no. 3, pp. 245-257, 1974.

[101] B. S. Starr and M. S. Starr, "Behavioural interactions involving $\mathrm{D}_{1}$ and $\mathrm{D}_{2}$ dopamine receptors in non-habituated mice," Neuropharmacology, vol. 26, no. 6, pp. 613-619, 1987.

[102] E. A. Stone, S. J. Manavalan, Y. Zhang, and D. Quartermain, "Beta adrenoceptor blockade mimics effects of stress on motor activity in mice," Neuropsychopharmacology, vol. 12, no. 1, pp. 65-71, 1995.

[103] M. I. Damaj, "Influence of gender and sex hormones on nicotine acute pharmacological effects in mice," Journal of Pharmacology and Experimental Therapeutics, vol. 296, no. 1, pp. 132-140, 2001. 
[104] R. C. MacPhail, J. D. Farmer, K. A. Jarema, and N. Chernoff, "Nicotine effects on the activity of mice exposed prenatally to the nicotinic agonist anatoxin-a," Neurotoxicology and Teratology, vol. 27, no. 4, pp. 593-598, 2005.

[105] S. J. Wanchoo, M. J. Lee, A. C. Swann, and N. Dafny, "Bilateral six-hydroxydopamine administration to PFC prevents the expression of behavioral sensitization to methylphenidate," Brain Research, vol. 1312, pp. 89-100, 2010.

[106] T. E. Wooters, N. M. Neugebauer, C. R. Rush, and M. T. Bardo, "Methylphenidate enhances the abuse-related behavioral effects of nicotine in rats: intravenous self-administration, drug discrimination, and locomotor cross-sensitization," Neuropsychopharmacology, vol. 33, no. 5, pp. 11371148, 2008.

[107] P. B. Yang, A. C. Swann, and N. Dafny, "Chronic methylphenidate modulates locomotor activity and sensory evoked responses in the VTA and NAc of freely behaving rats," Neuropharmacology, vol. 51, no. 3, pp. 546-556, 2006.

[108] A. Torres-Reverón and D. L. Dow-Edwards, "Repeated administration of methylphenidate in young, adolescent, and mature rats affects the response to cocaine later in adulthood," Psychopharmacology, vol. 181, no. 1, pp. 38-47, 2005.

[109] Y. Itzhak and J. L. Martin, "Effect of the neuronal nitric oxide synthase inhibitor 7-nitroindazole on methylphenidate-induced hyperlocomotion in mice," Behavioural Pharmacology, vol. 13, no. 1, pp. 81-86, 2002.

[110] K. L. Metzger, C. R. Maxwell, Y. Liang, and S. J. Siegel, "Effects of nicotine vary across two auditory evoked potentials in the mouse," Biological Psychiatry, vol. 61, no. 1, pp. 23-30, 2007.

[111] J. M. Phillips, R. S. Ehrlichman, and S. J. Siegel, "Mecamylamine blocks nicotine-induced enhancement of the P20 auditory event-related potential and evoked gamma," Neuroscience, vol. 144, no. 4, pp. 1314-1323, 2007.

[112] E. D. Levin and A. H. Rezvani, "Nicotinic interactions with antipsychotic drugs, models of schizophrenia and impacts on cognitive function," Biochemical Pharmacology, vol. 74, no. 8, pp. 1182-1191, 2007.

[113] A. H. Rezvani, D. P. Caldwell, and E. D. Levin, "Chronic nicotine interactions with clozapine and risperidone and attentional function in rats," Progress in Neuro-Psychopharmacology and Biological Psychiatry, vol. 30, no. 2, pp. 190-197, 2006.

[114] E. D. Levin, A. Petro, and D. P. Caldwell, "Nicotine and clozapine actions on pre-pulse inhibition deficits caused by $\mathrm{N}$ methyl-D-aspartate (NMDA) glutamatergic receptor blockade," Progress in Neuro-Psychopharmacology and Biological Psychiatry, vol. 29, no. 4, pp. 581-586, 2005.

[115] E. J. Popke, A. J. Mayorga, C. M. Fogle, and M. G. Paule, "Effects of acute nicotine on several operant behaviors in rats," Pharmacology Biochemistry and Behavior, vol. 65, no. 2, pp. 247-254, 2000.

[116] Y. Tizabi, J. Mastropaolo, C. H. Park et al., "Both nicotine and mecamylamine block dizocilpine-induced explosive jumping behavior in mice: psychiatric implications," Psychopharmacology, vol. 140, no. 2, pp. 202-205, 1998.

[117] K. Suemaru, K. Yasuda, K. Umeda et al., "Nicotine blocks apomorphine-induced disruption of prepulse inhibition of the acoustic startle in rats: possible involvement of central nicotinic $\alpha 7$ receptors," British Journal of Pharmacology, vol. 142, no. 5, pp. 843-850, 2004.

[118] H. Javelot, A. Baratta, L. Weiner et al., "Two acute psychotic episodes after administration of bupropion: a case of involuntary rechallenge," Pharmacy World and Science, vol. 31, no. 2, pp. 238-240, 2009.
[119] T. Javelot, H. Javelot, A. Baratta, L. Weiner, M. Messaoudi, and P. Lemoine, "Acute psychotic disorders related to bupropion: review of the literature," Encephale, vol. 36, no. 6, pp. 461-471, 2010.

[120] J. Bailey and S. Waters, "Acute psychosis after bupropion treatment in a healthy 28-year-old woman," Journal of the American Board of Family Medicine, vol. 21, no. 3, pp. 244245, 2008.

[121] M. Hahn, T. Hajek, M. Alda, and J. M. Gorman, "Psychosis induced by low-dose bupropion: sensitization of dopaminergic system by past cocaine abuse?" Journal of Psychiatric Practice, vol. 13, no. 5, pp. 336-338, 2007.

[122] C. H. Chan, H. C. Liu, and M. C. Huang, "Delirium associated with concomitant use of low-dose bupropion sustained release and fluoxetine," Journal of Clinical Psychopharmacology, vol. 26, no. 6, pp. 677-679, 2006.

[123] T. S. Wang, I. S. Shiah, C. B. Yeh, and C. C. Chang, "Acute psychosis following sustained release bupropion overdose," Progress in Neuro-Psychopharmacology and Biological Psychiatry, vol. 29, no. 1, pp. 149-151, 2005.

[124] M. Kraemer, J. Uekermann, J. Wiltfang, and B. Kis, "Methylphenidate-induced psychosis in adult attention-deficit/hyperactivity disorder: report of 3 new cases and review of the literature," Clinical Neuropharmacology, vol. 33, no. 4, pp. 204-206, 2010.

[125] C. Greiner, E. Enß, and E. Haen, "Drug-induced psychosis after intake of a modified-release formulation of methylphenidate," Psychiatrische Praxis, vol. 36, no. 2, pp. 89-91, 2009.

[126] A. D. Mosholder, K. Gelperin, T. A. Hammad, K. Phelan, and R. Johann-Liang, "Hallucinations and other psychotic symptoms associated with the use of attention-deficit/ hyperactivity disorder drugs in children," Pediatrics, vol. 123, no. 2, pp. 611-616, 2009.

[127] R. G. Ross, "Psychotic and manic-like symptoms during stimulant treatment of attention deficit hyperactivity disorder," American Journal of Psychiatry, vol. 163, no. 7, pp. 11491152, 2006.

[128] C. Curran, N. Byrappa, and A. McBride, "Stimulant psychosis: systematic review," British Journal of Psychiatry, vol. 185, pp. 196-204, 2004.

[129] M. Bruggisser, A. Ceschi, M. Bodmer, M. F. Wilks, H. Kupferschmidt, and M. E. Liechti, "Retrospective analysis of stimulant abuse cases reported to the Swiss Toxicological Information Centre during 1997-2009," Swiss Medical Weekly, vol. 140, article w13115, 2010.

[130] S. E. McCallum, A. C. Collins, R. Paylor, and M. J. Marks, "Deletion of the beta 2 nicotinic acetylcholine receptor subunit alters development of tolerance to nicotine and eliminates receptor upregulation," Psychopharmacology, vol. 184, no. 3-4, pp. 314-327, 2006.

[131] L. P. Dwoskin, A. S. Rauhut, K. A. King-Pospisil, and M. T. Bardo, "Review of the pharmacology and clinical profile of bupropion, an antidepressant and tobacco use cessation agent," CNS Drug Reviews, vol. 12, no. 3-4, pp. 178-207, 2006.

[132] S. K. Billes and M. A. Cowley, "Inhibition of dopamine and norepinephrine reuptake produces additive effects on energy balance in lean and obese mice," Neuropsychopharmacology, vol. 32, no. 4, pp. 822-834, 2007.

[133] C. E. John and S. R. Jones, "Voltammetric characterization of the effect of monoamine uptake inhibitors and releasers on dopamine and serotonin uptake in mouse caudate-putamen and substantia nigra slices," Neuropharmacology, vol. 52, no. 8, pp. 1596-1605, 2007. 
[134] N. Sidhpura, P. Redfern, H. Rowley, D. Heal, and S. Wonnacott, "Comparison of the effects of bupropion and nicotine on locomotor activation and dopamine release in vivo," Biochemical Pharmacology, vol. 74, no. 8, pp. 1292-1298, 2007.

[135] O. T. Ukairo, S. Ramanujapuram, and C. K. Surratt, "Fluctuation of the dopamine uptake inhibition potency of cocaine, but not amphetamine, at mammalian cells expressing the dopamine transporter," Brain Research, vol. 1131, no. 1, pp. 68-76, 2007.

[136] P. Weikop, J. Kehr, and J. Scheel-Krüger, "Reciprocal effects of combined administration of serotonin, noradrenaline and dopamine reuptake inhibitors on serotonin and dopamine levels in the rat prefrontal cortex: the role of 5-HT1A receptors," Journal of Psychopharmacology, vol. 21, no. 8, pp. 795804, 2007.

[137] L. M. Marubio, A. M. Gardier, S. Durier et al., "Effects of nicotine in the dopaminergic system of mice lacking the alpha4 subunit of neuronal nicotinic acetylcholine receptors," European Journal of Neuroscience, vol. 17, no. 7, pp. 1329-1337, 2003.

[138] M. R. Picciotto, M. Zoli, R. Rimondini et al., "Acetylcholine receptors containing the $\beta 2$ subunit are involved in the reinforcing properties of nicotine," Nature, vol. 391, no. 6663, pp. 173-177, 1998.

[139] S. R. Grady, N. M. Meinerz, J. Cao et al., "Nicotinic agonists stimulate acetylcholine release from mouse interpeduncular nucleus: a function mediated by a different nAChR than dopamine release from striatum," Journal of Neurochemistry, vol. 76, no. 1, pp. 258-268, 2001.

[140] J. E. Rose and W. A. Corrigall, "Nicotine self-administration in animals and humans: similarities and differences," Psychopharmacology, vol. 130, no. 1, pp. 28-40, 1997. 

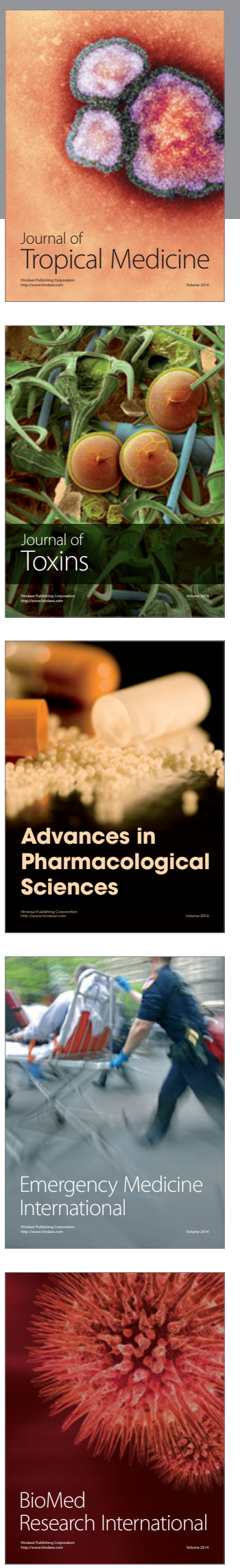
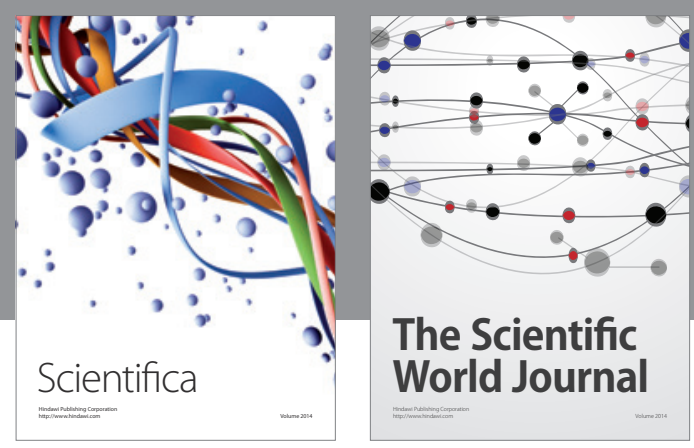

The Scientific World Journal
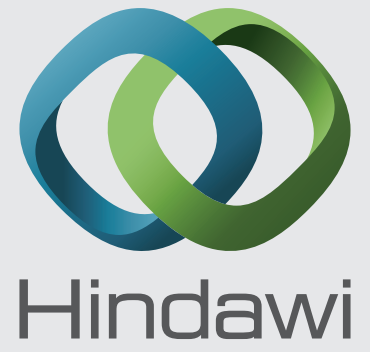

Submit your manuscripts at

http://www.hindawi.com
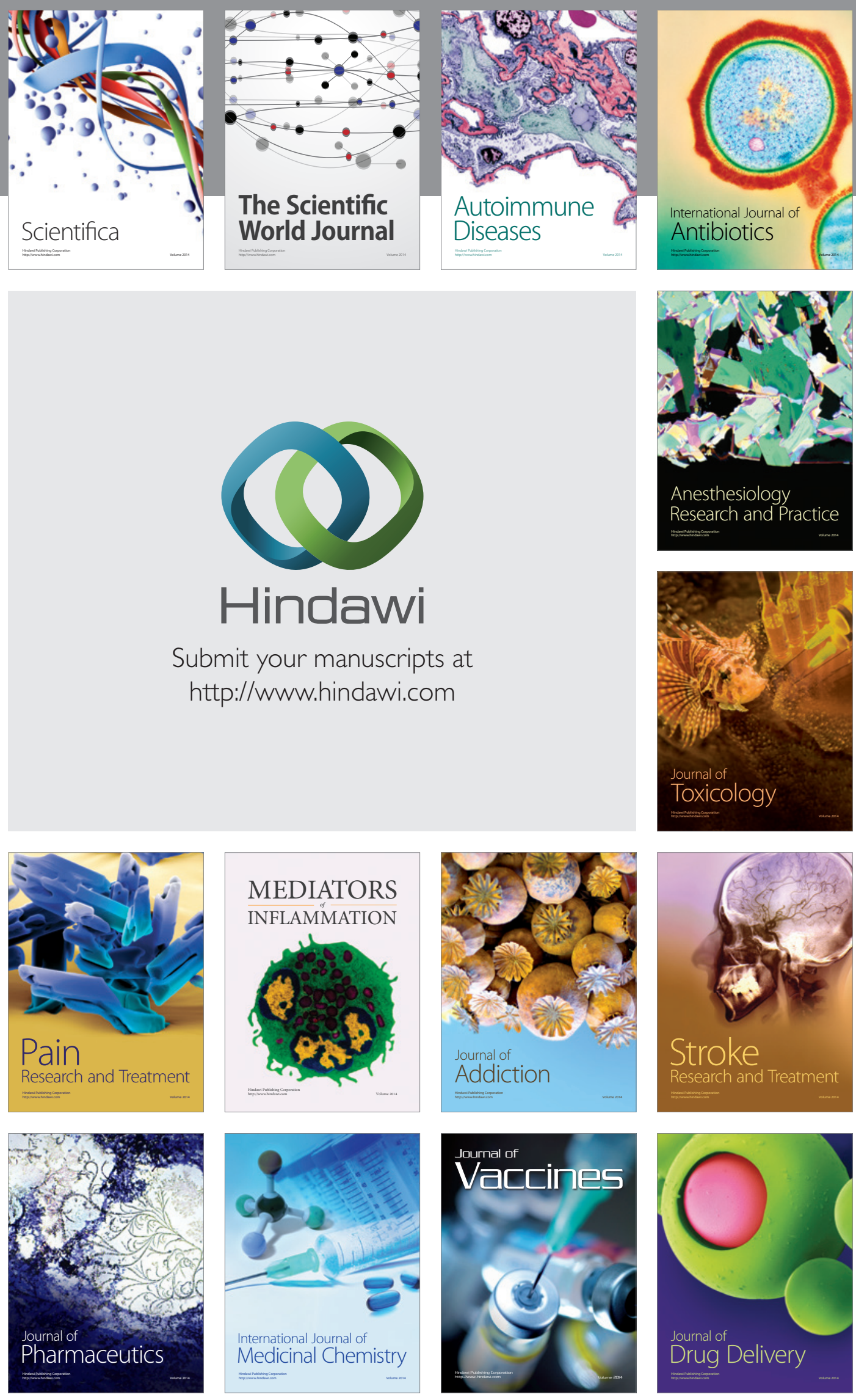